Previous: Bullshit and the Metaphor of Speaking One's Mind: Keynote Address by Phil Eubanks

Next: Power by Deception: Mamet's Matters of Confidence by Christophe Collard

\title{
Legible Liars:
}

Thackeray's Barry Lyndon as Professor of Imposture

Elizabeth Bleicher

Pivot is published through Open Journal Systems (OJS) at York University 
Barry Lyndon, W. M. Thackeray's comedic anti-hero, rightfully earned his reputation as one of the most notoriously unreliable narrators in English fiction, not least for his portrayal as an insatiably ambitious roving confidence man. Set in the $18^{\text {th }}$ century, the novel employs the conventions of the popular 'gentleman scoundrel' genre and constitutes Thackeray's acknowledged homage to Fielding's Jonathan Wild (1743), a fictional account of England's most notorious gentleman scoundrel to that point. ${ }^{1}$ Despite the Legible Liars: Thackeray's Barry Lyndon as Professor
of Imposture Elizabeth Bleicher distance provided by such historical and literary framing devices, scholars have long assumed Victorian readers found the highly mobile gambler with dozens of aliases both frightening and irredeemably bad. ${ }^{2}$ I wish to suggest that Barry Lyndon's literary appeal as well as his commercial liability were rooted in Thackeray's decision to cast his protagonist as a professor and philosopher of narrative proliferation. The sheer volume and variety of his attempts at imposture make Barry Lyndon (1844) an effective case study for analyzing how name

\footnotetext{
${ }^{1}$ In 1840, Thackeray praised Fielding, his favorite novelist, describing his attraction to Jonathan Wild, "an ironic study not only of criminality, but also of society's definition of the terms 'greatness' and 'heroism'" (qtd. in Sanders $\mathrm{x}-\mathrm{xi}$ ). Though Thackeray would eventually come to describe his own protagonist as unlikable, I would argue that Barry's attempts to change his life through imposture were heroic in scale and quantity.

2 The assumption of audience distaste is a fraught one, promoted even by Thackeray's most illustrious biographers Gordon Ray and George Saintsbury. It is based on the idea that readers disliked an unsympathetic protagonist or rebelled against the sharpness of Thackeray's satire. Contributing factors inferred include poor sales for the periodical issues in which the novel was originally serialized, the fact that the book was not released as a bound volume until well after Thackeray had become famous for Vanity Fair (1848), and the recollection by his cousin that he had given up on writing it because he was "afraid" of his audience (Beddingfield 12).
} 
and identity manipulation functioned in the exploration of selfdetermination that consumes much of $19^{\text {th }}$-century British fiction.

\section{Imposture}

Characters who engage in identity play were known in the Victorian era by the pejorative term 'impostor.' I have adopted it here as an historically accurate and etymologically rich shorthand that yields important resonances: to impose on another is to cause inconvenience or obligation, to assert control or authority. Read in this light, imposture is necessarily negative. However, the practice of identity manipulation most frequently designated as imposture can be read as an admirable attempt to exert personal agency within a particular historical moment.

Literary impostors are valuable subjects of study because they exaggerate the practices necessary to all identity construction, and do so to such an extent that they render the process and strategies visible. No Victorian literary character offers a better, more pedagogically conscious exemplar than does Barry Lyndon. Impostors perceive the gap between their assigned signifier and their consciousness. The radicalism of their rebellion is the implication that one's given name may be declined, that by the assertion of will one can be a different, self-made, kind of man. This is a form of personal and social mobility by which individuals empower themselves to craft a new, sometimes more accurate personal narrative; but then the onus is on the individual to promote, distribute, and gain social acceptance for the new identity.

With advances in the transportation system and the rapidly evolving moral and economic relationship to risk, mid-century Victorian readers were in the best possible position to imagine and recognize opportunities for pursuing new identities. While the desire for self-determination was not new to the Victorians, the industrial capital and technological innovations to realize it were unique to the period. The ability to physically transport oneself to a new place and begin a new life was a reality for an increasing 
number of individuals, but the cost of that unprecedented freedom was the anonymity of the city and the loss of geographical guarantees for identity claims that had accompanied rural and village life.

Even though, throughout the novel, Barry alleges to be educating readers in the finer points of professional gambling, he is actually delineating the rules for playing with one's identity, an endeavour far more interesting and alarming than his ostensible tutoring in how to circumvent the $19^{\text {th }}$-century reader's increasingly middleclass work ethic. ${ }^{3}$ Contrary to political and religious discourses' definitions of gambling as a lazy and thus immoral means for generating 'bad' money, Barry actually labours hard and constantly, which personal efforts mid-century Victorians valorized. The trouble is that he is not making salable commodities but manufacturing personal narrative-something many Victorian readers made anxious by industrial migration may have wished was authentic, unique, and thus beyond the grimy reach of industrial production. True to the fate of impostors in most Victorian novels, Barry uses his assorted names, titles, and narratives with varying degrees of intermediate success but with consistently disappointing final results. I want to suggest that his failures have very little to do with The Luck of Barry Lyndon, which is the ironic title under which the novel was originally serialized, and everything to do with his perpetually inadequate grasp of the complex of skills that forms the modus operandi for successful impostors. Victorian readers could learn plenty from his mistakes.

The discussion that follows examines two scenes from Barry Lyndon in an attempt to sketch the outlines of some terms for discussing name and identity manipulation. Robyn Warhol rightly argues that the point of any critical model is not to force it on

\footnotetext{
${ }^{3}$ See Franklin for an elegant and useful analysis of the discourse of gambling in Victorian novels, as well as the threat gambling posed to the rising middle class.
} 
books to see if it fits, but to consider what employing it might or might not do for us as readers and scholars (21-2). To those ends, I have developed three terms to describe the system of operation I see among impostors, their practices, and their circumstances and communities within a variety of Victorian novels, but most especially in Barry Lyndon. Novels are cultural artefacts that shape, exploit, reflect, and attempt to satisfy readers' and societies' desires. The more I read the clearer it became that Victorian readers were hungry for greater certainty about others and increased freedom for themselves; novels provided access to a broader variety of people than a reader might hitherto have encountered in person, as well as methods for dealing with strangers. Barry Lyndon was chosen as the case study for assaying the utility of these terms by virtue of the frequency with which imposture is attempted within its pages, and the explicit and realistic delineation of the process by which an agent learns how to conduct an identity manipulation, as well as what the consequences of seizing that freedom can be.

Furthermore, the model these terms may constitute is predicated on the understanding of identity not as an essence, but rather as a nexus of narratives developed for strategic deployment. ${ }^{4}$ In this model, successful identity manipulation depends upon the mastery of three interdependent competencies: interpersonal literacy, recursive scripting, and confidence networking.

\section{Interpersonal Literacy}

At its most concrete level, interpersonal literacy means the ability to 'read' people and to decipher individual and community responses to self-representations, which imply a consciousness that one is being read. Physiognomy, the study of faces, is an ancient practice, though readers of $19^{\text {th }}$-century fiction are better

\footnotetext{
${ }^{4}$ This study is informed in part by the work of Judith Butler, most especially the conception of identity that she articulates in her book Gender Trouble and by the extensive body of scholarship built on her foundational premises. I read identity as the social performance of an accreted complex of narratives.
} 
acquainted with Austen's witty accounts of Elizabeth Bennet's attempts to decipher Mr. Darcy via his brow and mouth than Confucius's or Aristotle's discourses on the connection between character and appearance. My urge to develop a more contemporary term was born out of the immediacy of the need to assess anxieties that advances in transportation and technology aroused in Victorian readers.

Developing interpersonal literacy requires training in visual and verbal cueing, investigating, gathering sources, inquiring subtly, exploiting events and circumstances, practicing scepticism without paranoia, and identifying and monitoring the components of 'character' and reputation; it is an accreted complex of skills. The scenes under consideration here illustrate Barry's incremental development of interpersonal literacy, as well as the hazards of interpersonal illiteracy, which Thackeray paints as a liability in a system that would come to be known as social Darwinism by the late 1870 s.

\section{Recursive scripting}

Self-fashioning, which has been studied extensively from the Renaissance to contemporary studies of passing, is obviously not exclusive to $19^{\text {th }}$-century England. What is interesting to me is the way in which the rise of the novel and social anxieties over identity combine to help novels evolve from morality textbooks into practical instruction for coping with the stressors of modernity. Faking is fun, but characters like Barry Lyndon reveal for Victorian readers how much is at stake and how sophisticated the methods for personal transformation have become. Narrative self-fashioning and attentive, rigorous, vigilant maintenance and management of that narrative are required; and it is this complex of practices to which I refer as recursive scripting.

In mapping the moves of impostors, I see imposture as an act of exchange and negotiation; anyone may tender a new personal narrative, but the story has no meaning without validation by an audience. Identity manipulation cannot be reduced to a simple 
transmitter/receiver exercise. This exchange is a socially contingent process of writing, revising, and retransmitting a personal narrative. The relationship between interpersonal literacy and recursive self-scripting can be likened to sonography: a successful individual takes a series of soundings to chart the contours of a culture and the people in it, then develops and deploys an appropriate narrative. The community echoes back a response indicating belief, suspicion, acceptance, or rejection, in part or in whole. If the claim is not wholly rejected, the character can adjust the performance to accommodate new information and variables. Thus, the exchange is a recursive process of mutually influencing, reinforcing, affirming, and invalidating encounters.

\section{Confidence Networking}

The confidence network is the field within which an impostor conducts a narrative experiment. It is formed not simply of persons, but of events, competing values, conventions, circumstances, and social, economic, and political institutions that rely on each other to construct a mutually authenticating assessment of an individual's character. Confidence networking, similar in function to contemporary professional networking, entails a participant's developing knowledge to navigate and exploit the system to achieve success.

There are numerous theories on how communities exercise quality control and socialize newcomers. Irving Goffman argues that when a society generates a frame of reference for an individual, indicating acceptance of his identity claims, then the self-protection rules for ferreting out misrepresentation are suspended; but once the frame is contested, evidence takes on new meaning and all parties must re-evaluate their de facto opponents (149). In a similar vein, Michael de Certeau argues that in coping with the rise of urban and consumer culture, people came to be both frugal and provincial with their psychic investments (43). Accepting mutually reinforcing assessments of a newcomer's worthiness for inclusion in the community is a 
matter of convenience so members do not have to do so much interpersonal reading. But Victorian literary examples of the perils of such frugality can be found in the fiscally cautionary tales of Merdle in Dickens's Little Dorrit (1855) and Melmotte in Trollope's The Way We Live Now (1871). Both Merdle and Melmotte are more skilled confidence networkers than is Barry, not least because they were created for readers whose interpersonal literacy skills had been cultivated by an additional decade or two of reading Victorian novels.

The Victorian predilections for inventory management and taxonomy evoked Adam Smith's 1766 description of England as "a nation of shopkeepers" (358), and they provide a helpful analogy for considering the relationships among impostors, their interpersonal literacy and self-scripting skills, and the confidence network in which they operate. Every impostor wants her or his new name and story to be socially accepted, and every community wants to eliminate the anxiety of uncertainty by investigating and defining the individual, locating her or him on the spectrum of worthiness, and then filing the newcomer away as known 'inventory' or casting her or him out as a danger. The relationship is one of paradoxically competing and mutual desires; if it sounds like a game, it should, for this is how Barry Lyndon explicitly treats identity play, as discussed more fully below.

I offer these terms as an historically specific means of studying how an impostor's practices enable us to excavate and reconstruct the methods by which such characters demonstrate to readers how to play with one's identity, the results identity manipulators can expect, strategies to avoid being taken advantage of, and individual and community responses to those who generate multiple personal narratives.

Barry Lyndon, born Redmond Barry, is the braggart only child of an Irish family with more pretence than money. The novel that describes Barry's adventures opens with a lengthy soliloquy on his 
name and its history that renders it, and him, suspect from the start:

I presume that there is no gentleman in Europe that has not heard of the house of Barry of Barryogue, of the Kingdom of Ireland, than which a more famous name is not to be found ... and though as a man of the world I have learned to despise heartily the claims of some pretenders to high birth who have no more genealogy than the lackey who cleans my boots ... yet truth compels me to assert that my family was the noblest of the island.... I would assume the Irish crown over my coat of arms, but that there are so many silly pretenders to that distinction who bear it and render it common. (3, italics in the original)

It will prove significant that his name is the device by which we learn that Barry is in all things given both to exaggeration and boasting. We learn that he has been trained in self-promotion by his mother, a scheming beauty and a skilled pedagogue in the rules of shabby gentility. She has literally and figuratively embroidered the family coat of arms, manufacturing physical evidence to support grand narrative claims for their name: "We were princes.... This I know to be the fact, for my mother has often told me the story, and besides had worked it in a worsted pedigree which hung ... at Barryville where we lived" (4). The irony and the pun in a "worsted pedigree" would not have been lost on Thackeray's keen readers.

Barry's mother ensures that her son has fundamental knowledge about self-representation insofar as he knows that it is both possible and desirable to attempt to influence the way others perceive him. In Chapter III, titled "I Make a False Start in the Genteel World," our hero recounts his flight to Dublin as a young man because he mistakenly believes he has killed a man in a duel. At the suggestion of his cousin and his mother, relative amateurs at identity manipulation, he travels under the name of "Mr. Redmond," a facile, novice's choice of a new alias for being 
an easily decoded reversal of his real name, Redmond Barry. Without any maternal prompting, he soon embellishes his alias with what he thinks will be an aristocratic flourish "of the Waterford Redmonds" (52) and determines to be taken for a gentleman in his new life. As he understands lavish spending and drinking oneself to sleep to be two important criteria for credibility, he is careful to tell the reader, "I made a point to act the fine gentleman completely, and, I assure you, succeeded in my part to admiration" (49). Even at this early stage, he is aware that the successful deployment of his new identity is, and will require the maintenance of, a performance to validate the proffered story of his identity.

Unfortunately, Barry's first performance will ultimately be sabotaged by his under-developed ability to read others and his obliviousness to the fact that they are reading him. This weakness is revealed at the outset of his escape to Dublin wherein he reports being quizzed by a fellow traveler on the road:

I made part of the journey ... with a well-armed gentleman ... dressed in green and a gold cord, with a patch on his eye and riding a powerful mare. He asked me ... whither I was bound, and whether my mother was not afraid on account of the highwayman to let one so young as myself to travel? But I said, pulling out one of them from a holster, that I had a pair of good pistols that had already done execution and were ready to do it again; and here ... he put spurs into his bay mare and left me. She was a much more powerful animal than mine, and besides, I did not wish to fatigue my horse, wishing to enter Dublin ... in reputable condition. (50)

Barry is so personally illiterate that he fails to realize that at he is talking to none other than the Highwayman himself. While we experienced readers of literature and other persons note such literary conventions as the traveler's excessive arms, fine clothing, and the eye-patch advertising his piratical identity, these clues are lost on Barry, who assumes he has merely been 
snubbed. In terms of his progress as a budding impostor, he at least knows enough to arrive in Dublin in a manner consistent with the fine gentleman he claims to be, not a windblown rider on a lathered mount.

Further down the road, Barry sees a crowd surrounding a carriage from which his former companion is bounding away. He there discovers Mrs. Fitzsimons, whose jewels and money have just been liberated. Barry offers himself to the dame in distress as an armed escort into Dublin and a "young gentleman of large fortune," owning parenthetically to the reader that "this was not true; but what is the use of crying bad fish? My mother instructed me early in that sort of prudence" (52). His recollection of maternal tutelage underscores the idea that identity manipulation is a learned discipline and participates in the nascent middle-class Victorian discourse of self-improvement that is developing outside the pages of the book. But here as throughout the novel, Barry has dangerous overconfidence in the quality of his scripting skills:

These mishaps I sincerely commiserated; and knowing her by her accent to be an Englishwoman, deplored the differences ... between the two countries, and said that in our country (meaning England) such atrocities were unknown. "You, too, are an Englishman?" said she, with rather a tone of surprise. (51)

Barry thinks he is reading her by her accent and identifies her as a representative of a superior race, as the more prejudiced of Thackeray's British readers might also have done; but Barry fails to realize that she is reading him as an Irish country boy so provincial as to mistake a town-dweller's dialect for the language of a different country. When she cautions him about the rogues and adventurers he will meet in Dublin, we glimpse the delicious irony that Mrs. Fitzsimons herself may be a sort of highwayman in drag (52).

Mrs. Fitzsimons clearly has the more highly developed level of interpersonal literacy; but her quick recognition and appropriation 
of the mistaken identity Barry has constructed for her also reveals her effective mastery of the second foundational skill of successful identity manipulation: recursive scripting. Exploiting what she reads as his ignorant response to her self-presentation, she plays his assumptions and the part he has scripted for her to her advantage, and commences aggressively dropping the names of people of whom Barry is "too well bred" to admit he does not know (52). Their initial encounter illustrates the extent to which identity manipulation entails exchange, negotiation, and revision.

Once in Dublin, Barry makes a fresh attempt at self-scripting, but proves less proficient than his hostess, who takes him to tatty dwellings that belie her claims to society, and introduces him to a coarse spouse who professes to know the Redmonds of Waterford very well,

which assertion alarmed me, as I knew nothing of the family to which I was stated to belong. But I posed him by asking which of the Waterford Redmonds he knew, for I had never heard his name in our family. He said he knew the Redmonds of Redmondstown. 'Oh,' says I, 'mine are the Redmonds of Castle Redmond; and so I put him off the scent. (54, italics in the original)

This is still an amateur's move on Barry's part, and experienced readers see the humour in Captain Fitzsimons's equally obvious name-gaming, which is so rudimentary as to suggest that he is deliberately testing Barry's interpersonal literacy. Beneath the humour of this exchange, however, lie the tensions over names that were at work in the culture outside the novel's pages.

It is crucial to consider that the serialized numbers of Barry Lyndon were coming out in Fraser's Magazine in tandem with one of the largest commercial promotional campaigns in England's history. For 1844 marked both the onset of the mid-century Railway Mania (1844-47) and the passage of Gladstone's Regulation Act that mandated low-cost universal access to rail travel. In 1844 trains were poised to become a major agent of 
social democratization among classes. The rise of physical mobility combined with the loss of an individual's geographic pedigree, such as Redmondstown or Castle Redmond, had simultaneously heightened concerns over and attenuated the ability of a community to verify newcomers' identity claims.

As noted above, self-scripting is a recursive process of reflexive encounters. These take place within the confidence network, which ultimately determines the agent's success or failure by exerting its power to confirm or deny identity claims. Just as one person or event in the confidence network can spark a chain reaction of doubt, so too can a member draw confidence and validation from the cumulative acceptance of an individual's projected persona. What Barry frequently fails to realize is that the most common trigger of doubt is inconsistency, whether between or within narrative and performance. Barry is wise to prevent Captain Fitzsimons from sniffing out the "scent" of inconsistency in his identity claim because he needs to secure multiple investments of trust in order to be authenticated by the confidence network and live successfully under his assumed identity.

As a result, Captain and Mrs. Fitzsimons serve as his professional references, and bring Barry into their circle of fast company who quickly lighten his purse via card and horse gambling. To keep their own game going, Barry's hosts introduce him to the local merchants as a wealthy gentleman; taking confidence from the Fitzsimons' assessment of his identity claims, they give Barry goods and services on credit and are beholden to (and more generous with) the Fitzsimonses for bringing them new business. The Fitzsimonses' character reference is the first step toward building a reputation within the confidence network that will make Barry's tendered identity narrative acceptable to the community. With the first offer of credit, he will have convinced two parties that he is who he claims to be, and this constitutes a frame of reference for him that generates fiscal and social credibility. It is 
important to note that others are now doing the impostor's work for him, for in its capacity as a device of mutual authentication, the confidence network can be seen as supporting and participating in the very practices it ostensibly seeks to discover and prevent. ${ }^{5}$ In this case, it promotes an impostor's cause since doing so works to the community's short-term financial benefit.

Despite his progress, the limits of Barry's underdeveloped interpersonal literacy are exposed when he is so completely immersed in his new role that he inquires at the post office for letters to Mr. Redmond. A more advanced player would realize they would never come: his mother has addressed them all to his real name, Mr. Barry. She is not proficient enough in the art of imposture to know that he must conduct all his business in character to maintain the consistency required by the confidence network.

As the weeks wear on and the Fitzsimonses' syndicate empties his purse, Barry is compelled to pawn for cash the fine new clothes he used as props for performing his new identity, and he hits bottom on the day he learns his new name is no longer good for credit, his horse is impounded, and promissory notes drawn in the names of his gambling friends are worthless. Returning to the lodgings he shares with the Fitzsimonses, he discovers that they have rifled through his belongings and found evidence of his real name:
"Whom have I been harboring in my house? ... You are an impostor, young man ... Mr. REDMOND BARRY ... You represent yourself as heir of my friends the Redmonds of Castle Redmond ... I take you to my tradesmen, who give

\footnotetext{
${ }^{5}$ This seemingly hypocritical and paradoxical move is at the heart of $D$. A. Miller's discussion of the effects of Victorian fiction on morality, and the proliferation of tales predicated on the reader's detective skills during the period. His work, as well as the present study, is firmly grounded in the principles of social control articulated by Michel Foucault. However, I wish to cast impostors' practices as individual interventions into what would otherwise be a closed and monolithic system of social control.
} 
you credit, and what do I find? That you have pawned the goods that you took up at their houses."

"I have given them my acceptances, sir," said I with a dignified air.

"Under what name, unhappy boy-under what name?" screamed Mrs. Fitzsimons; and then, indeed I remembered that I had signed the [pawnbroker's] documents Barry Redmond, instead of Redmond Barry. ... After uttering a furious tirade against me ... he spoke of the fatal discovery of my real name upon my linen. $(60)^{6}$

Had Barry a more developed level of interpersonal literacy, he would have realized that his gentle host had just trapped himself in a lie, since Fitzsimonses had originally claimed to know the Redmonds of Redmondstown. It was Barry who claimed the geographic identity guarantee of Castle Redmond. He might also have turned to his advantage the fact that his self-righteous benefactor had been in a pawnshop himself, given that both of their visits to such an establishment are radically inconsistent with identity narratives of wealth and nobility.

The confidence network of people within which Barry tendered his claims detected an inconsistency between his narrative and his performance, which triggered a domino effect of doubt and cued the Fitzsimonses to take steps to alleviate the anxiety of their suspicions and investigate the frame they had constructed for Barry as a rich, unworldly dupe. What they found destroyed their frame and shredded the script of Barry's new, constructed

\footnotetext{
6 Theoretically, Barry would have been exposed for using his real name at the pawnbrokers, not the alias he remembers tendering. This would have given the Fitzsimonses grounds for doubting his claim, but the fact that he used his alias means that, unlike his mistake at the post office, he knew enough to remain in character during business transactions, even though this meant committing commercial fraud. So what at first glance appears to be a logical error is in fact the Fitzsimonses alerting him to the fact that they know he has committed a legally actionable crime. For discussion of Thackeray's tendency to disregard factual error, see McCarthey and Shillingsburg.
} 
identity. Prior to departure, his mother embroidered his belongings with his real name. The retention of such damaging physical evidence turns his original clothing into Barry's identification papers. Further, Thackeray adds another layer of irony in that the monogram, the symbol of the family name, was literally inscribed by the hand of the family member who taught Barry to embroider his name figuratively. The same hand that worked his "worsted pedigree" reaches out of the past and stitches him to his old identity.

In their rage, the Fitzsimonses threaten to turn him over to the law, but Barry is successful in an attempt at recursive selfscripting, albeit late in the game: he reclaims his real name and uses the original reason for his imposture, the ostensible murder, to threaten them. Their decision to permit him to escape is much to their mutual benefit since the swindling ring might otherwise be exposed. At chapter's end Barry discloses himself "frankly" as "young gentleman in difficulties" to the one person least interested in knowing his real identity: a recruiter for the King's army who needs a mass of bodies, not an identifiable individual (62).

The fourth chapter, "In Which Barry Takes a Near View of Military Glory" is followed by the humorous fifth, "In Which Barry Removes as Far as Possible from Military Glory." The latter offers a vivid illustration of the rapid development of Barry's skills in interpersonal literacy, self-scripting, and confidence networking, which are accelerated by Barry's drive to escape a rigid military hierarchy that is inherently inhospitable to attempts at social climbing and circumventing the rules. Only a few pages after his disastrous attempt at being Mr. Redmond, Barry is swaggering about Germany under the name of "Captain Barry" despite the fact that he is a corporal. He is close to getting himself courtmarshalled when a head injury sustained at the hands of a man he is attempting to cheat out of money presents him with a unique opportunity to launch a new identity. Barry is taken to the 
home of a blind man and his daughter who are also nursing his archenemy Lt. Fakenham, a superior officer who had publicly humiliated him. Though Fakenham develops a fever and hallucinations, Barry heals quickly. When a commander asks why Barry did not rejoin his regiment when it left for the front, Barry takes a lesson from the feverish Fakenham and stages a relapse by pretending to be mad, raving at the nurse, claiming he is Julius Caesar and pronouncing the visiting doctor to be his affianced wife Cleopatra (75).

Barry's manoeuvre astutely seizes an opportunity to engage in some creative confidence networking. All those capable of corroborating Barry's "real" name have gone to the front. Additionally, by tendering the name of a real, very famous and very dead person, he has not claimed to be insane, but his claim to such an obviously false identity convinces the doctor to officially validate-and circulate within the confidence networkthe new identity Barry actually desires: that of a mad man. Barry now understands how to get the confidence network to do his work for him.

When the doctor leaves for the front, Barry begins to "recover" and woos Lischen, the nurse, both for pleasure and profit: he is advanced enough at networking to cultivate a corroborator for the next draft of his identity narrative. He then frightens off Fakenham's servant and attends to the irascible patient himself. What appears to be altruism is in fact a strategy for conducting an identity theft. Barry reveals: "I was determined to escape, and to escape under the character of Lieutenant Fakenham.... It was forgery and robbery if you like; for I took all his money and clothes ... I knew I could not effect my escape without his purse, as well as his name" (77). Barry has dispatched the last person who could attest to the Lieutenant's real identity, and has clearly learned the lesson of the tell-tale clothes: he understands the value of evidence to support his performance. 
Barry acts perfectly sane when the doctor comes for a second visit. With corroboration from his girlfriend the nurse, he convinces the surgeon that the man up in the sickroom is really "the mad corporal." The brief exchange among Barry, the nurse, and the new doctor demonstrates the operation of the confidence network in action.

"Good morrow, corporal," said the doctor, rather gruffly, in reply to my smiling salute.

"Corporal! Lieutenant, if you please," answered I, giving an arch look at Lischen, whom I had not yet instructed in my plot.

"How lieutenant?" asked the surgeon. "I thought the lieutenant was-"

"Upon my word, you do me great honour," cried I, laughing; "you mistook me for the mad corporal upstairs. The fellow has once or twice pretended to be an officer, but my kind hostess can answer which is which."

"Yesterday he fancied he was Prince Ferdinand," said Lischen; "the day you came he said he was an Egyptian mummy."

"So he did," said the doctor; "I remember; but ha! ha! do you know lieutenant, I have in my notes made a mistake in you two?" ...

Lischen and I laughed at his error as the most ridiculous thing in the world. (77)

Barry recalls this scene to suggest that using corroborated personal testimony to verify an identity claim has the power not only to undermine the effectiveness of physical evidence, such as the doctor's notes, but also to actually cause the doctor to doubt his own judgment, even when supported by ostensibly concrete proof. Recall that as the components of the confidence network work simultaneously to categorize an individual as a known 
subject, they influence, undermine, and authenticate each other to forge a unified assessment of an individual's identity. The psychological tactic of ridicule that Barry and Lischen so adroitly employ derives much of its power from the assertion of inequalities in knowledge and awareness that it implies. Barry uses derision to reposition the doctor, arguably an established and representative authority within the confidence network, as the suspect agent. The only recourse available to the individual to whom such a tactic is applied is to feign knowingness or risk reassessment by the confidence network her or himself.

After the doctor has been successfully befuddled and cowed, Barry dons Fakenham's uniform, ensures there is no one from his old regiment left in town to recognize him, and finally steals Fakenham's purse and identity papers, awakening the victim in the process: "'You gweat scoundwel!', said he, with a multiplicity of oaths.... 'As sure as my name is Fakenham, when we get back to the wegiment, I'll have your soul cut out of your body!'” (78, italics in the original).

The Lieutenant's exclamation offers more than a comedic moment; it is Thackeray's sly meditation on the nature of identity and it reflects his original readers' anxieties about the increasing inability to know others. The lieutenant's oath to separate Barry's soul from his body is based on the humanist assumption that the two are ineluctably linked; one gives meaning and definition to the other, much as a name was presumed to identify a particular person. To attempt to part body and soul is certain and violent death in Fakenham's cosmology, and arguably the Victorian reader's as well.

Though it would have been distressing to the average Victorian reader, the Derridian concept of play is particularly apt for the study of a gambler and identity player such as Barry, and for illuminating the lack of fixed meaning between a name and an individual that Thackeray leads modern thinkers to consider (Derrida 278-95). Indeed, once stolen, the name constitutes a 
classic Thackerayan pun by representing a truer match between signifier and signified than it ever did for its original owner, for even in his imperfect performance, Barry is clearly the better "faking ham." Barry's greatest talent is, in fact, revealing and exploiting the interstices in the confidence network and the gap between signifier and signified, as amply demonstrated by the table below:

\section{The Names of Barry Lyndon}

Self-generated

Barry of Barryogue (3)

Redmond Barry (15)

Captain Barry $(16,66>)$

Mr. Redmond (48)

Barry Redmond (60)

Julius Caesar (75)

An Egyptian mummy (76)

Redmond Barry of Bally Barry, descendant of Irish Kings (84)

Lt. Fakenham (77) (impersonation)

Redmond de Balibari (128)

Chevalier Redmond de Balibari (155)

Young Chevalier de Balibari (178)

Redmond Barry, Esq. (186)

Chevalier Barry, Chamberlain to the Duke of Hohenzollern-Sigmaringen (199)

Dermott (219)

Captain Fireball (203) (written pseudonym)

Captain Thunder (222) (written pseudonym)

Barry Lyndon (233) (legally changed by King's permission to wife's name)

The humble Irish adventurer (256)
Given by others (but used or accepted by Barry)

English Redmond $(6,14)$

Black Englander (103)

Schwarzer Englander (103)

English Devil (103)

Impostor (57)

Ambrose (125)

My Lord (66)

Wicked Barry (284)

Devil Lyndon (284)

Caliban (291)

Jailer (291)

Tyrant (291)

Dark Spirit (291)

Felon caitiff (291)

Woman's Bully (298)

Artless Irish Rustic (182) 
Earl of Barry (257) (goal attempted,

never achieved)

Viscount of Ballybarry (257) (goal

attempted, never achieved)

Baron of Barryogue (259)

Not content with changing his name, Barry re-names houses and his child, as well. Upon the presumed death of his stepson, he pronounces his biological son Bryan the Lord Viscount CastleLyndon (278). The crumbling family estate BallyBarry becomes BallyBarry Castle (242). Even his mother gets in on the act by declaring that Brady Town is now Barryville, and she is Mrs. Barry of Lyndon (280).

By cataloguing Barry's narrative and onomastic products, I wish to suggest that the threat he posed for Victorian readers was less his gambling, fraudulence, and social climbing than his insistence on the constructedness and malleability of identity. ${ }^{7}$ No other character in $19^{\text {th }}$ - century British literature so persistently embodies the idea that identity is not essential, but is rather a series of accreted iterations of narrative gambits. Barry exposes this with his aggressive narrative self-fashioning to illuminate the opportunities for intervention into a process of identity formation that offers more possibility for selfdetermination than did the unified humanist subject.

Barry is a gambler by trade and by nature who stakes everything (as do most impostors) on the temporary reprieve that a new name and life-story offer, knowing that this is a drastically contingent life. Gamblers expect to lose sometimes in

\footnotetext{
${ }^{7}$ In the absence of contemporary records that would solve the mystery of the serial version's presumed commercial failure, scholars have been forced to hypothesize from circumstantial evidence. To the usual factors cited, I would add Trollope's insistence in that the novel is not a training manual for gambling and vice, along with Leslie Stephen's 1856 review aimed at asserting a moral foundation within the tale, which suggests that Victorian readers had significant reservations about the ethical implications of raising a peripatetic gambler to the level of fit literary subject.
} 
the service of the occasional big win. However, what looks like a loss to a contemporary reader may be read as a win for a character learning the process of launching identities and enjoying the temporally limited, but nonetheless significant exercises of self-determination and agency that they constitute. In his failures, Barry is not unique, as $19^{\text {th }}$-century literary impostors are almost never completely or ultimately successful. Readers of Victorian fiction know that a social transgressor like Barry cannot be allowed to succeed; fiction has long been used to teach and police social boundaries, and readers in troubled times need especially the comfortable literary convention of resolution.

In this light, Thackeray's plot can be read as one long sequence of name and identity manipulations that follow the pattern of the two cycles discussed above: attempt, success, discovery, then downfall and social excommunication. Barry's successes and failures constitute the laboratory notes for a series of personal narrative experiments, and in so doing plot his learning curve, which is far more educational than his failure to live as a wealthy gentleman of social renown. In comparison to the Redmond Barry episode, the Fakenham imposture demonstrates that Barry is exponentially more aware of what it will take to succeed at inhabiting a new personal narrative. He reads the situation correctly, seizes an opportunity, revises his narrative in response to changing circumstances, secures valuable physical evidence and first-person corroboration, and even colonizes the confidence network to assign a new identity in place of the one he stole. As Barry escapes the house under the barrage of Fakenham's tirade, he attributes the noise to "the mad corporal," a name that will prove impossible for the lisping lieutenant to shake (78).

Long after the resolution of the Fakenham incident and its illustration of Barry's newly acquired skills, Barry explicitly spells out the rules of the real game. The ease with which he wins and 
loses millions, as well as Thackeray's authorial decision for Barry to narrate the memoir from his final home in debtors' prison, undermine the easy assumption that the lesson to be learned is about gambling, as our unreliable narrator claims. The reality is that Barry's aggressive games are not about making money but about making something of himself. As he succinctly puts it: "Play with me is only a means to an end" (152). His most deliberate, direct instruction establishes a framework by which readers can organize the explicit and implicit rules for playing with one's identity that he accumulates and demonstrates throughout the novel:

Do you suppose that any man ... will not take all the advantages that his neighbour enjoys? They are all the same. But it is only the clumsy fool who cheats.... Such a man is sure to go wrong at some time or another ... [M]y advice to people who see such a vulgar person at his pranks is, of course, to back him while he plays, but never have anything to do with him. Play grandly, honourably. Be not, of course, cast down at losing; but above all, be not eager at winning, as mean souls are. ... [W] hen one considers the time and labour spent, the genius, the anxiety, the outlay of money required, the multiplicity of bad debts that one meets with (for dishonourable rascals are to be found at the play-table, as everywhere else in the world), I say, for my part, the profession is a bad one; and, indeed, have scarcely ever met a man who, in the end, profited by it. I am writing now with the experience of a man of the world. ... [S]implicity was our secret. Everything successful is simple. ... [I]t is always far the best way ... to tell as much truth as my story would possibly bear. (11819)

From this template, Professor Lyndon's rules for playing with one's identity may be collected under four interdependent basic premises and summarized from the rest of the novel as follows. 
1. Identity play is a complex of skills that can be learned. Play dumb or be quiet so others will speak freely around you (118). Be observant of others and their moves to anticipate the next ones (119 onward). Take advantage of others' weaknesses (throughout). Practice makes perfect $(22,160)$. Consult a trusted expert (205). Watch and imitate professional players (117 onward). Try small experiments to gain experience for big launches (Chapters 4 and 6).

2. Knowledge is power. Cheat if you can get away with it (118). Use strategic narrative, not devices or evidence that can be used against you. Destroy the evidence of an old identity $(60,165)$. Manufacture evidence as needed to support your identity claims (257) but rely more on story; evidence opens up increased liability (60). Try to speak only from experience and do your homework (90). Do not have secrets; they make you vulnerable to blackmail (149). Know your opponent $(90,219)$. Distance yourself from bad characters who might expose you or contaminate the confidence network by association $(86,231)$.

3. Performance counts. Be mindful of the confidence network. Profit from others who cheat but protect yourself from them personally (118). Be aware that others are engaged in the same endeavours as you (276). A new name and fresh territory are required to launch a new personal narrative (48). If you fail or are not good at juggling all this, keep moving. Make others and the confidence network do your work for you (206, 223, 228, $230,231)$. Work the system by determining how to give people what they want to help you win (257). Play the games others expect in order to conduct your own (264). Play big and pay your losses graciously to appear to be a member of the class you are claiming (118). Be consistent in your story and your performance. Do not let them see you sweat over your losses or rejoice in your wins; one implies need, the other discourages more play (118). 
4. Keep it simple. Always choose skill and narrative over devices and evidence to reduce your liability $(60,77)$. Be as honest as possible to help you keep your own story straight (119).

Attentive readers can infer that the most basic requirements for launching a new identity experiment are fresh territory, a new name and narrative, corroboration, and a consistent performance to support the narrative. Barry demonstrates that successful identity play can be extended and enhanced by travel, lack of geographical guarantees, disproportionate levels of interpersonal literacy between participants, personal confidence, acting ability, risk tolerance, intelligence, and imagination. An agent has to be able to imagine a different existence in order to identify, seize, or create an opportunity to shape and launch one.

Barry's lessons in lying and rendering liars legible, and the model for studying identity manipulation that his prolific impostures suggest, give us a way to think about identity construction and self-determination within a historically and culturally specific period. Along with the pleasures of reading novels about imposture, we, like the Victorians, can derive pleasure in cultivating our own interpersonal literacy so that we may read others more effectively, even as we study how we revise our own scripts and navigate the confidence networks we encounter. 0

\section{Works Cited}

Bedingfield, Richard. "Recollections of Thackeray: Prologue." Cassell's Magazine 2 Sep. 1870: 12-14. Print.

Butler, Judith. Gender Trouble. New York: Routledge, 1990. Print.

de Certeau, Michael. The Practice of Everyday Life. Berkeley: $U$ California P, 1988. 
Derrida, Jacques. "Structure, Sign and Play in the Discourse of the Human Sciences." Writing and Difference. Transl. Alan Bass. Chicago: U of Chicago P, 1980. 278-94. Print.

Foucault, Michel. Discipline and Punish: The Birth of the Prison. New York: Vintage, 1995. Print.

Franklin, Jeffrey. Serious Play: The Cultural Form of the Nineteenth-century Realist Novel. Philadelphia: U Penn P, 1999. Print.

Goffman. Erving. The Goffman Reader. Eds. Charles Lemert and Ann Braneman. Malden, MA: Blackwell, 1997. Print.

Miller, D.A., The Novel and the Police. Berkeley: U California P, 1989.

McCarthey, Terrence. "Chronological Inconsistencies in Barry Lyndon." English Language Notes 21.2 (1983): 29-37. Print.

Ray, Gordon. Thackeray: The Uses of Adversity. New York: McGraw Hill, 1955. Print.

Saintsbury, George. A Consideration of Thackeray. New York: Russell \& Russell, 1931. Print.

Sanders, Andrew. "Introduction." The Memoirs of Barry Lyndon, Esq. Ed. Andrew Sanders. Oxford: Oxford UP, 1999. Print. Shillingsburg, Peter. Pegasus in Harness: Victorian Publishing and W.M. Thackeray. Charlottesville: UP Virginia, 1992. Print.

Smith, Adam. An Inquiry into the Wealth of Nations. Ed. Kathryn Sutherland. New York: Oxford UP, 2008. Print.

Stephan, Leslie. "Barry Lyndon." Saturday Evening Review 27 Dec. 1856: 783-85. Print. 
Thackeray, William Makepeace. The Memoirs of Barry Lyndon, Esq. Ed. Andrew Sanders. Oxford: Oxford UP, 1999. Print.

Trollope, Anthony. Thackeray. New York: Macmillen, 1879. Print.

Warhol, Robyn. Gendered Interventions: Narrative Discourse in the Victorian Novel. New Brunswick: Rutgers UP, 1989. Print.

Elizabeth Bleicher is Assistant Professor of English and Coordinator of English Education at Ithaca College in Ithaca, New York, where she is a member of the Honors Program faculty. She teaches and conducts research on Victorian literature and culture, liberal and higher education, and pedagogical methods for teaching literature, writing and critical thinking. 